\title{
Soil Texture Influence on Meloidogyne incognita and Thielaviopsis basicola and Their Interaction on Cotton
}

J. Jaraba, Universidad de Cordoba, Monteria, Cordoba, Colombia; C. S. Rothrock, Department of Plant Pathology, University of Arkansas, Fayetteville 72701; T. L. Kirkpatrick, University of Arkansas Southwest Research and Extension Center, Hope 71801; and K. R. Brye, Department of Soil, Crop, and Environmental Sciences, University of Arkansas, Fayetteville

\begin{abstract}
Jaraba, J., Rothrock, C. S., Kirkpatrick, T. L., and Brye, K. R. 2014. Soil texture influence on Meloidogyne incognita and Thielaviopsis basicola and their interaction on cotton. Plant Dis. 98:336-343.

Microplots were used to evaluate the impact of soil texture on Meloidogyne incognita, Thielaviopsis basicola, and their interaction on cotton. A native silt loam soil (48\% sand) and four different artificial soil textures produced by mixing native soil with sand $(53,70,74$, and $87 \%$ sand) were studied. Each soil texture was infested with 0,4 , or 8 M. incognita eggs and 0 or $20 \mathrm{~T}$. basicola chlamydospore chains per gram of soil in a factorial treatment arrangement. Plots were watered when soil moisture fell below -10 joules/kg for the first 21 days and -30 joules $/ \mathrm{kg}$ from 22 days to harvest. Plant growth was suppressed early in the season and midseason by $T$. basicola. M. incognita suppressed plant growth and delayed plant development late in the season

across all soil textures. Cotton yield was lower in the presence of either T. basicola or M. incognita. An interaction between $M$. incognita and T. basicola, which decreased plant growth and yield, occurred in 2006 when neither pathogen caused substantial plant damage. Plant growth, development, and yield were lowest in soils with $>74 \%$ sand. Root colonization by $T$. basicola and fungal reproduction and survival decreased in soil having $87 \%$ sand. M. incognita generally caused more galling and reproduction in soils as sand content increased. Root galling severity and $M$. incognita reproduction were suppressed by the presence of $T$. basicola in soil at sand contents lower than $87 \%$. Soil texture had a greater impact on T. basicola than on M. incognita in this study.
\end{abstract}

The root-knot nematode Meloidogyne incognita (Kofoid \& White) Chitwood and the soilborne fungus Thielaviopsis basicola (Berk. \& Broome) Ferraris (syn. Chalara elegans Nag Raj \& W.B. Kendr.), the causal agent of black root rot, are important plant pathogens of upland cotton (Gossypium hirsutum L.) (16). M. incognita is the most widely-distributed nematode pest of cotton worldwide (18). Black root rot has become an important seedling disease on cotton throughout the world $(1,20)$.

Root-knot nematodes emerge from eggs as second-stage juveniles (J2s) and penetrate cortical root tissue immediately behind the root cap. After migrating to the vascular tissue, they establish a permanent feeding site, eliciting morphological and physiological changes that include the formation of root galls (21). Both soil temperature and texture influence root-knot nematode damage and reproduction. Soil temperatures of 25 to $30^{\circ} \mathrm{C}$ favor nematode embryogenesis and egg hatch (36), while temperatures below $10^{\circ} \mathrm{C}$ are inhibitory (8). Population densities of the nematode are inversely related to silt and clay contents $(10,17,28)$. Reproduction of $M$. incognita was greater in soils with sand contents of 58 or $91 \%$ than soils with lower sand contents (17), and damage to cotton increased at greater sand content $(24,27)$. Soil moisture may also affect survival of the nematode, with survival being greater in soils at water pressures of $-0.11 \mathrm{MPa}$ than in soil at $-0.016,-0.03,-1.5$, or $-9.2 \mathrm{MPa}(35)$.

T. basicola overwinters as thick-walled chlamydospores that germinate in the presence of the host and adequate soil water $(11,25)$. $T$. basicola usually colonizes the root cortical tissue, causing darkbrown to black discoloration of the roots and hypocotyl $(1,19,20)$.

Corresponding author: C. S. Rothrock, E-mail: Rothrock@uark.edu

* The $\boldsymbol{e}$-Xtra logo stands for "electronic extra" and indicates that four supplementary tables are available in the online edition.

Accepted for publication 31 August 2013.

http://dx.doi.org/10.1094/PDIS-04-13-0357-RE

(C) 2014 The American Phytopathological Society
Under high disease pressure, hyphae and chlamydospores of the fungus have been observed within the vascular system of upland cotton roots $(15,20)$. Black root rot is most severe when soils are cool (below $24^{\circ} \mathrm{C}$ ) and wet (above -20 joules $/ \mathrm{kg}$ ) $(14,30,38)$. As soil temperatures increase and roots mature, affected cortical tissues are sloughed off and secondary root growth occurs $(19,20)$. Within a field, lower soil populations of T. basicola were associated with soil textures having $65 \%$ sand or greater (22). In controlled studies using soils infested with a benomyl-resistant strain of $T$. basicola at 100 chlamydospores/g of soil, soils with sand contents of $56 \%$ or greater suppressed black root rot compared with soils with lower sand content (4).

A synergistic interaction between $M$. incognita and T. basicola has been described in cotton (23,37-39). Concrete microplots infested with both $T$. basicola and M. incognita showed an increase in seedling death and a decrease in plant growth compared with microplots infested with either pathogen alone. Plants affected by both the root-knot nematode and T. basicola had fewer bolls per plant, a reduction in boll retention at the second fruiting position, and reduced seed-cotton yields compared with plants grown in soils infested with either pathogen alone or in noninfested plots (37). Plant damage associated with this interaction increased as population densities of the individual pathogens increased (39). Infection of cotton by both $T$. basicola and M. incognita appeared to increase the effective range of temperatures at which both pathogens caused damage $(23,38)$. Histological studies detected the presence of $T$. basicola frequently in the vascular root tissue in plants grown in soils infested with $M$. incognita, suggesting that cotton roots affected by the nematode allowed $T$. basicola to colonize vascular tissues that are not normally colonized in the absence of the nematode (38). The presence of $T$. basicola reduced nematode reproduction $(23,37-39)$. The objective of this study was to examine the influence of soil texture on the reproduction and damage potential of $M$. incognita and T. basicola and their interaction on cotton.

\section{Materials and Methods}

A native silt-loam soil (48\% sand, 50\% silt, and 2\% clay) from a field at the Delta Branch Station, Clarkedale, AR (Dubbs-Dundee 
complex mixed, thermic Typic Hapludalfs), with a long history of cotton monoculture was used to make four artificial soil textures $(53,70,74$, or $87 \%$ sand) by mixing the native soil with sand $(>2$ $\mathrm{mm}=6.3 \%, 1$ to $2 \mathrm{~mm}=11.0 \%, 0.5$ to $1 \mathrm{~mm}=21.6 \%, 0.25$ to 0.5 $\mathrm{mm}=41.5 \%, 0.1$ to $0.25 \mathrm{~mm}=16.9 \%$, and 0.05 to $0.1 \mathrm{~mm}=$ $2.75 \%$ ) using an electric cement-mixer (model CM350A; Northern). Texture for each soil was determined using the hydrometer particle-size method (2). Microplots consisting of clay flue tiles ( 45 by $30 \mathrm{~cm}$ wide and $75 \mathrm{~cm}$ deep) that had previously been established at the Arkansas Agricultural Research and Extension Center, Fayetteville, were used. The empty tiles were disinfested by spraying the walls with $0.5 \% \mathrm{NaOCl}$ until run-off. The soil mixtures were steam pasteurized for $30 \mathrm{~min}$ at $70^{\circ} \mathrm{C}$ prior to use. Prior to placing the soil into the microplots, samples were taken from each soil texture and oven dried to calculate soil water content. Soil for each microplot was divided into five portions by weight, added in $15-\mathrm{cm}$ increments, and packed to a bulk density of $1.1 \mathrm{~g} / \mathrm{cm}^{3}$. After a layer was compacted, the surface was disturbed with a rake before the addition of soil for the next layer.

Inoculum. $T$. basicola isolate $3 \mathrm{~N}-25 \mathrm{~B}$, recovered from cotton seedlings at the Delta Branch Station near Clarkedale, AR, was used to prepare the fungal inoculum. Chlamydospore chains were obtained by the screening procedure described by Candole and Rothrock (6). Briefly, 6-week-old cultures of T. basicola grown on $10 \%$ carrot juice agar were flooded with sterile distilled water and decanted repeatedly to dislodge endoconidia. Chlamydospore chains and other fungal structures were removed from plates with a rubber policeman, suspended in sterile distilled water, and passed through a monofilament nylon fabric with $53-\mu \mathrm{m}$ openings (Tetko, Inc.). The suspension was then filtered through a monofilament nylon fabric with $20-\mu \mathrm{m}$ openings. Chlamydospores chains retained on the nylon fabric were transferred into a sterile 50-ml centrifuge tube containing about $20 \mathrm{ml}$ of sterile distilled water and stored in a refrigerator at 2 to $5^{\circ} \mathrm{C}$. The suspension containing chlamydospore chains were plated on carrot juice agar, incubated for $24 \mathrm{~h}$, and examined to determine percent chlamydospore germination.

$M$. incognita, host race 3, was provided by the Arkansas Nematode Diagnostic Clinic, University of Arkansas Southwest Research and Extension Center at Hope. The nematode population was originally collected from cotton in a producer's field in Arkansas. For microplot inoculum, the isolate was increased on tomato (Lycopersicon esculentum L. 'Rutgers') in a greenhouse. Eggs were collected from infected roots after $75 \mathrm{~d}$ using $\mathrm{NaOCl}$ as described by Hussey and Barker (12).

Microplot establishment. Microplots were infested with $T$. basicola to obtain 20 chlamydospore chains (approximately 100 individual chlamydospores) per gram of oven dry weight (ODW) equivalent of soil in the top $15-\mathrm{cm}$ layer of soil. Chlamydospores were suspended in $50 \mathrm{ml}$ of sterile distilled water and applied with a hand trigger sprayer to each soil texture, and the soil was mixed in a cement mixer. Infested soils were placed in microplots above the four layers of noninfested soil and packed to a depth of $15 \mathrm{~cm}$. $M$. incognita eggs and $\mathrm{J} 2 \mathrm{~s}$ were suspended in sterile distilled water, and applied into two holes $(1 \mathrm{~cm}$ in diameter by $5 \mathrm{~cm}$ deep) for each microplot at planting to obtain a final rate of 4 or 8 eggs and $\mathrm{J} 2 \mathrm{~s} / \mathrm{g}$ of soil (ODW) in the top $15 \mathrm{~cm}$ of soil.

Six pathogen treatments were included for each soil texture: a noninfested control, $T$. basicola alone, the two rates of $M$. incognita alone, and all combinations of M. incognita and T. basicola in 2006 and 2008. The microplots were planted in 2007 without reinfesting plots, using the surviving populations from the 2006 season as inoculum. Prior to planting in 2008, soil from each microplot was removed to a depth of $75 \mathrm{~cm}$ and steam pasteurized. The pasteurized soil for each texture was used to refill the microplots as described for 2006 and the top $15 \mathrm{~cm}$ was infested at appropriate pathogen levels, as described.

Fourteen acid-delinted seeds of 'DP 444 BG/RR' cotton (Delta and Pine Land) were planted in each plot immediately following infestation. Planting dates were 16 May in both 2006 and 2007. In 2008, 'DP 555 BG/RR' was used and the planting date was 17
May. Seed were treated with the fungicides triadimenol, thiram, and metalaxyl $(0.107,0.326$, and $0.152 \mathrm{~g}$ a.i./kg of seed, respectively; RTU Baytan-Thiram and Allegiance, Bayer CropScience). Soil fertility analysis was performed on a composite soil sample taken from each soil texture prior to planting, and each microplot was fertilized with $0.7,0.6$, and $0.15 \mathrm{~g}$ of $\mathrm{N}, \mathrm{K}$, and $\mathrm{S}$, respectively, 15 and 50 days after planting (DAP) based on recommendations of the University of Arkansas Division of Agriculture Soil Testing and Research Laboratory, Marianna. Plants were sprayed with MiracleGro water-soluble fertilizer (24-8-16) at $4 \mathrm{~g} /$ liter if nitrogen deficiency symptoms were observed. Cotton plants were sprayed with the insecticide dicofol at $277.5 \mathrm{~g}$ a.i./ha (Kelthane 18.5 EC; Rohm and Haas Company) to control mites in 2006 and 2007.

Soil temperature and moisture data were collected using soil temperature and watermark soil moisture sensors connected to a data logger (WatchDog, model 450) in one microplot for each soil texture. Soil moisture also was measured in each texture with a ThetaProbe ML2 (Delta-T Devices). Air temperature and rainfall data were obtained from a weather station at the Arkansas Agricultural Research and Extension Center, Fayetteville (26). All microplots for each soil texture were watered when they reached a matric potential of approximately -10 joules $/ \mathrm{kg}$ for the first 21 days and -30 joules $/ \mathrm{kg}$ from 22 days to harvest by watering with the equivalent of $1.5 \mathrm{~cm}$ of rainfall. Percent water for each matric potential was determined for each soil texture using a Haines' apparatus, a Buchner funnel with a fine sintered-glass base plate, prior to initiating the study (9).

Plant and disease assessment. At 12 DAP, seeding emergence was assessed, and the number of plants was thinned to six plants per plot. Two plants were arbitrarily sampled from each microplot at 22 to 28 DAP (early-season) and at 45 to 50 DAP (midseason), and 2 plants were left until harvest. Plants were measured for height from the cotyledonary node to the tip of the main stem terminal and the number of main stem leaf nodes was counted for each plant. The portion of plant above the cotyledonary node was removed, dried at $60^{\circ} \mathrm{C}$ for $48 \mathrm{~h}$, and weighed. Root systems from each plant were rinsed with tap water for $20 \mathrm{~min}$, immersed for 2 $\min$ in $0.5 \% \mathrm{NaOCl}$, blotted dry in a paper towel, and weighed. Roots were rated for root discoloration using a scale of 0 to 10 , where $0=0 \%, 1=1$ to $10,2=11$ to $20,3=21$ to $30,4=31$ to 40 , $5=41$ to $50,6=51$ to $60,7=61$ to $70,8=71$ to $80,9=81$ to 90 , and $10=91$ to $100 \%$ of the root system discolored. Root systems then were evaluated for nematode galling on a scale of 0 to 5 , where $0=0,1=1$ to $2,2=3$ to $10,3=11$ to $30,4=31$ to 50 , and $5=51$ to 100 galls/root system. Roots were plated on the medium TB-CEN (32), amended with Penicillin G (ICN Biomedicals Inc.) at $60 \mathrm{mg} /$ liter. Plates were kept in the dark at room temperature $(20$ to $23^{\circ} \mathrm{C}$ ) and, after 12 to 14 days, the percentage of root systems with growth of $T$. basicola on the medium was rated using the 0-to10 scale described previously for root discoloration. At harvest, cotton plants were cut below the cotyledonary node and mapped for growth and development using COTMAP (3). Lint and seed were hand harvested from each microplot to assess seed cotton production per plant.

Pathogen populations. $M$. incognita and $T$. basicola populations were assessed from soils at 22 to 28,45 to 50 , and 120 to 130 DAP (late-season) and in spring (2 April 2007 and 2008 and 5 April 2009). A composite soil sample taken with a 2.5 -cm-diameter sampling tube to a depth of $15 \mathrm{~cm}$ was collected from each plot. Population density of $T$. basicola was determined by the pour-plate technique using amended TB-CEN medium. Briefly, $27 \mathrm{~g}$ of soil were suspended in $237 \mathrm{ml}$ of sterile water agar $(0.15 \%)$ for a total of $250 \mathrm{ml}$. Soil suspensions were shaken on a wrist action shaker for $20 \mathrm{~min}$, and $1 \mathrm{ml}$ of the sample was pipetted into each of the six petri plates (100 by $15 \mathrm{~mm}$ ) for a sample. Molten TB-CEN medium (approximately $45^{\circ} \mathrm{C}$ ) was poured into each plate and plates were swirled to uniformly distribute the soil suspension. Plates were kept at room temperature $\left(20\right.$ to $\left.23^{\circ} \mathrm{C}\right)$ in the dark and the number of colonies of $T$. basicola counted 12 to 14 days after plating. Counts were adjusted to CFU per gram of soil (ODW). 
Soil nematode populations were extracted by the Arkansas Nematode Diagnostic Clinic Laboratory, University of Arkansas Southwest Research and Extension Center. A $100-\mathrm{cm}^{3}$ subsample of soil from each plot was processed using a semiautomatic elutriator (5) followed by centrifugal flotation (13). M. incognita root populations were estimated by agitating the roots collected from the 100$\mathrm{cm}^{3}$ sample in a $0.5 \% \mathrm{NaOCl}$ solution (12) and collecting the eggs on a $500-$ mesh $(26-\mu \mathrm{m})$ sieve. Nematodes and eggs were counted with a stereoscope at a $\times 40$ to $\times 60$ magnification.

Statistics. The experiment was arranged in a randomized complete block design using a factorial arrangement of texture and pathogen treatments and four replications. Statistical analyses were conducted using the GLM procedure in SAS 9.2 (SAS Institute Inc.). Data were analyzed by year. Root discoloration, colonization, and galling were analyzed as midvalues. Pathogen populations were transformed using $\log _{10}(x+1)$ for statistical analyses. Treatment means were separated with Fisher's protected least significant difference (LSD) at $P=0.05$. When interactions were significant $(P \leq 0.05)$, appropriate interaction means were examined and LSDs were calculated. Treatments not receiving $M$. incognita were omitted from analyses for nematode populations and root galling, and treatments not receiving T. basicola were omitted from analyses for root discoloration and colonization.

\section{Results}

In 2006, daily soil temperatures at $10 \mathrm{~cm}$ averaged $22.1,24.6$, and $28.6^{\circ} \mathrm{C}$ and rainfall totals were $22.9,7.7$, and $10.9 \mathrm{~mm}$ from the time of planting in May, June, and July, respectively. In 2007, daily soil temperatures averaged $20.3,23.5$, and $26.3^{\circ} \mathrm{C}$ and rainfall was 5.2, 14.1, and $12.6 \mathrm{~mm}$ for the same periods of time, respectively. In 2008, soil temperatures averaged 23.5, 25.3, and $27.8^{\circ} \mathrm{C}$ and rainfall 13.714 .9 , and $19.4 \mathrm{~mm}$ from the time of planting in May, June, and July, respectively. Soil temperatures did not differ consistently among soil textures. Soil bulk density in the top $15 \mathrm{~cm}$ averaged $1.12,1.10,1.10,1.17$, and $1.10 \mathrm{~g} / \mathrm{cm}^{3}$ for the soils with $48,53,70,74$, and $87 \%$ sand content, respectively, when assessed after harvest in 2008.

Plant growth. Fewer differences were seen among treatments for early-season plant growth than at midseason or at harvest. $T$. basicola reduced plant height compared with plots that were not infested with $T$. basicola over all soil textures at 22 to 28 DAP in both 2007 and 2008: Infested height was $0.4 \mathrm{~cm}$ and noninfested height was $0.8 \mathrm{~cm}$ in $2007(P=0.0002)$, and 3.4 and $4.4 \mathrm{~cm}$, respectively, in $2008(P=0.0056)$. Similarly, numbers of nodes were 0.7 in infested and 1.3 in noninfested microplots in $2007(P=$ $0.0001)$ and 2.1 and 2.4 in $2008(P=0.0195)$. M. incognita reduced plant height and the number of nodes compared with plots that were not infested with the nematode over all soil textures in 2008 (3.7 or 3.0 to $5.1 \mathrm{~cm}[P<0.0001]$, and 2.1 or 2.1 to $2.6[P<$ $0.0001]$, respectively). T. basicola in 2007 reduced root weight compared with plots not infested with $T$. basicola over all soil textures at 0.175 to $0.301 \mathrm{~g}(P<0.0001)$, respectively. In 2008, a soil texture-T. basicola interaction occurred $(P=0.0187)$, with $T$. basicola reducing root weight compared with plots not infested with $T$. basicola at sand contents of 48,53 , or $74 \%$ (data not presented). No consistent effects were seen on early plant growth for soil texture (data not presented).

At midseason (45 to 50 DAP), soil texture, $M$. incognita, and T. basicola all affected plant height in all 3 years (Supplementary Table S1). Effects were generally independent, although a soil- $T$. basicola interaction and an $M$. incognita-T. basicola interaction were observed in 2006 for plant height. Both $M$. incognita and $T$. basicola reduced midseason plant height in 2007 and 2008 compared with the noninfested treatment (Table 1). T. basicola reduced plant heights $40 \%$ in 2007 and $9 \%$ in 2008, while plant height reductions with $M$. incognita averaged $40 \%$ in 2007 and $31 \%$ in 2008. Sand contents of 53 and $70 \%$ supported greater plant heights than $87 \%$ sand in both 2007 and 2008 (Table 1). T. basicola reduced plant height in soil with the lowest sand content (48\%) compared with plots not infested with T. basicola in 2006. Co-infection by $T$. basicola and $M$. incognita caused a greater suppression of plant height than either T. basicola or M. incognita alone in 2006 (Table 1). M. incognita also reduced plant height in the absence of $T$. basicola compared with the noninfested treatment.

For main stem leaf nodes, soil texture significantly affected growth in all 3 years and $M$. incognita and $T$. basicola significantly affected growth in 2007 and 2008. Interactions between soil texture and $M$. incognita and between $M$. incognita and T. basicola were present in 2007. No consistent effects of soil texture were observed for nodes (Table 1). Both $M$. incognita and T. basicola reduced the number of main stem nodes in 2008 compared with the noninfested

Table 1. Main and interaction effects of soil texture (sand), Meloidogyne incognita ${ }^{\mathrm{t}}(\mathrm{Mi})$, and Thielaviopsis basicola $^{\mathrm{u}}$ (Tb) at midseason season on plant height and number of main stem nodes ${ }^{\mathrm{V}}$

\begin{tabular}{|c|c|c|c|c|c|c|c|c|c|}
\hline \multirow[b]{2}{*}{ Main effect } & \multicolumn{4}{|c|}{ Plant height (cm) } & \multicolumn{5}{|c|}{ Main stem nodes } \\
\hline & \multicolumn{2}{|c|}{2006} & \multirow[t]{2}{*}{2007} & \multirow[t]{2}{*}{2008} & \multirow[t]{2}{*}{2006} & \multicolumn{3}{|c|}{2007} & \multirow[t]{2}{*}{2008} \\
\hline Sand $(\%)$ & \multicolumn{2}{|c|}{0 ------- Tb ----- 20} & & & & \multicolumn{2}{|r|}{$\begin{array}{c}\mathrm{Mi} \\
4\end{array}$} & & \\
\hline 48 & $36.8 \mathrm{a}^{\mathrm{w}}$ & $26.0 \mathrm{~cd}$ & $23.6 \mathrm{a}^{\mathrm{x}}$ & $18.3 \mathrm{c}^{\mathrm{x}}$ & $7.6 \mathrm{a}^{\mathrm{x}}$ & $7.7 \mathrm{a}^{\mathrm{y}}$ & $6.9 \mathrm{abcd}$ & $6.5 \mathrm{abcd}$ & $6.9 \mathrm{~b}^{\mathrm{x}}$ \\
\hline 53 & $32.5 \mathrm{ab}$ & $28.5 \mathrm{bc}$ & $23.3 \mathrm{a}$ & $25.1 \mathrm{~b}$ & $6.7 \mathrm{~b}$ & $7.6 \mathrm{ab}$ & $6.8 \mathrm{abcd}$ & $5.6 \mathrm{de}$ & $7.9 \mathrm{a}$ \\
\hline 70 & $26.3 \mathrm{~cd}$ & $28.5 \mathrm{bc}$ & $22.7 \mathrm{ab}$ & $29.0 \mathrm{a}$ & $7.0 \mathrm{ab}$ & $7.4 \mathrm{ab}$ & $5.4 \mathrm{de}$ & $6.9 \mathrm{abcd}$ & $7.8 \mathrm{a}$ \\
\hline 74 & $28.2 \mathrm{bc}$ & $24.1 \mathrm{cde}$ & $18.9 \mathrm{bc}$ & $14.2 \mathrm{~d}$ & $7.1 \mathrm{ab}$ & $7.4 \mathrm{ab}$ & $5.7 \mathrm{cde}$ & 6.1 bcde & $6.3 \mathrm{c}$ \\
\hline 87 & $22.1 \mathrm{de}$ & $19.5 \mathrm{e}$ & $17.1 \mathrm{c}$ & $19.2 \mathrm{c}$ & $6.6 \mathrm{~b}$ & $7.2 \mathrm{abc}$ & $5.1 \mathrm{e}$ & $5.1 \mathrm{e}$ & $6.9 \mathrm{~b}$ \\
\hline $\mathrm{Mi}$ & 0 -.-. & ---20 & & & & $0-$ & $-\mathrm{Tb}$ & -20 & \\
\hline 0 & $33.8 \mathrm{a}^{\mathrm{z}}$ & $33.2 \mathrm{a}$ & $29.1 \mathrm{a}$ & $27.2 \mathrm{a}$ & $7.3 \mathrm{a}$ & $7.7 \mathrm{a}^{\mathrm{z}}$ & & $7.2 \mathrm{a}$ & $7.9 \mathrm{a}$ \\
\hline 4 & $26.3 \mathrm{~b}$ & $21.9 \mathrm{c}$ & $17.2 \mathrm{~b}$ & $18.4 \mathrm{~b}$ & $7.0 \mathrm{a}$ & $6.9 \mathrm{a}$ & & $5.1 \mathrm{~b}$ & $6.7 \mathrm{~b}$ \\
\hline 8 & $27.4 \mathrm{~b}$ & $20.7 \mathrm{c}$ & $18.0 \mathrm{~b}$ & $18.9 \mathrm{~b}$ & $6.7 \mathrm{a}$ & $7.2 \mathrm{a}$ & & $4.9 \mathrm{~b}$ & $7.0 \mathrm{~b}$ \\
\hline \multicolumn{10}{|l|}{$\mathrm{Tb}$} \\
\hline 0 & & & $26.2 \mathrm{a}$ & $22.5 \mathrm{a}$ & $7.2 \mathrm{a}$ & & & & $7.4 \mathrm{a}$ \\
\hline 20 & & & $15.7 \mathrm{~b}$ & $20.4 \mathrm{~b}$ & $6.8 \mathrm{a}$ & & & & $7.0 \mathrm{~b}$ \\
\hline
\end{tabular}

${ }^{\mathrm{t}}$ Soils were infested at planting with 4 or 8 eggs and second stage juveniles (J2) of $M$. incognita/g of soil.

"Soils were infested at planting with 20 chlamydospore chains of $T$. basicola/g of soil.

${ }^{v}$ Plant growth variables were measured 45 to 50 days after planting.

${ }^{\mathrm{w}}$ Interaction means for any sand and $\mathrm{Tb}$ combination followed by the same letter are not significantly different, Fisher's protected least significant difference $(P \leq 0.05)$.

${ }^{\mathrm{x}}$ Means for a year and main effect followed by a common letter are not significantly different, Fisher's protected least significant difference $(P \leq 0.05)$.

${ }^{\mathrm{y}}$ Interaction means for any sand and Mi combination followed by the same letter are not significantly different, Fisher's protected least significant difference $(P \leq 0.05)$.

${ }^{\mathrm{z}}$ Interaction means for any Mi and $\mathrm{Tb}$ combination followed by the same letter are not significantly different, Fisher's protected least significant difference $(P \leq 0.05)$. 
treatment midseason regardless of differences in soil texture (Table 1). M. incognita at either or both infestation rates reduced the number of plant nodes in soils with a sand content $>48 \%$ compared with plots not infested with M. incognita in 2007 (Table 1). The number of nodes was lower in soil infested with $M$. incognita and T. basicola than in plots infested with either the nematode or the fungus, regardless of differences in soil texture in 2007 (Table 1).

At midseason, soil texture, $M$. incognita, and T. basicola affected root weight in all 3 years. A significant interaction between $M$. incognita and T. basicola or T. basicola and soil texture occurred for root weight in 2006 and 2007, respectively. M. incognita in 2007 and 2008 and T. basicola in 2008 reduced root weight compared with the noninfested treatment over all soil textures (Table 2). Root weights were lower for plants grown in soils infested with both pathogens than for plants grown in noninfested soil or soils with $M$. incognita or T. basicola alone in 2006. T. basicola reduced root weight in soil with sand contents of $74 \%$ or lower but not at $87 \%$ sand content in 2007 compared with treatments not infested with $T$. basicola. Soil textures of 74 or $87 \%$ sand had lower root weights compared with $53 \%$ sand in 2006 and 2008, and in 2007 for the noninfested soils only (Table 2).

Effects of T. basicola, $M$. incognita, and soil texture were independent for crop growth and development at the end of the season, except for a soil-T. basicola interaction in 2008 for plant height (Supplementary Table S2). Plants were shorter in $87 \%$ sand than other soil textures in both 2006 and 2007 and except for $74 \%$ sand in the presence of T. basicola in 2008 (Table 3). M. incognita reduced plant height in both 2007 and 2008. The nematode also influenced initiation of fruiting all 3 years, delaying the formation of the first sympodial branch on the main stem in plants grown in soil treated with one or both rates of $M$. incognita compared with plots not infested with $M$. incognita (Table 3 ). The position of the first sympodial branch was also higher in plants grown in soils infested with T. basicola in 2008.

Seed-cotton yield was affected by $T$. basicola, $M$. incognita, and soil texture in each year, with a significant $M$. incognita-T. basicola interaction in 2006. Yield was lower at sand contents of 74 or $87 \%$ than in 53 or $70 \%$ sand all 3 years (Table 3). Yield was

Table 2. Main and interaction effects of soil texture (sand), Meloidogyne incognita ${ }^{\mathrm{u}}(\mathrm{Mi})$, and Thielaviopsis basicola ${ }^{\mathrm{v}}(\mathrm{Tb})$ at midseason season on fresh root weight $^{\mathrm{w}}$

\begin{tabular}{|c|c|c|c|c|c|}
\hline \multirow[b]{2}{*}{ Main effect } & \multicolumn{5}{|c|}{ Fresh root weight (g) } \\
\hline & \multicolumn{2}{|c|}{2006} & \multicolumn{2}{|c|}{2007} & 2008 \\
\hline Sand $(\%)$ & & & 0 & ------20 & \\
\hline 48 & \multicolumn{2}{|c|}{$2.362 \mathrm{ab}^{\mathrm{x}}$} & $2.408 a^{y}$ & $1.241 \mathrm{~d}$ & $1.596 b^{x}$ \\
\hline 53 & \multicolumn{2}{|c|}{$2.496 \mathrm{a}$} & $3.125 \mathrm{a}$ & $0.972 \mathrm{~d}$ & $2.737 \mathrm{a}$ \\
\hline 70 & \multicolumn{2}{|c|}{$2.290 \mathrm{ab}$} & $2.186 \mathrm{bc}$ & $1.275 \mathrm{~d}$ & $2.787 \mathrm{a}$ \\
\hline 74 & \multicolumn{2}{|c|}{$2.075 \mathrm{~b}$} & $2.097 \mathrm{bc}$ & $0.905 \mathrm{~d}$ & $0.968 \mathrm{c}$ \\
\hline 87 & \multicolumn{2}{|c|}{$1.586 \mathrm{c}$} & $1.463 \mathrm{~cd}$ & $0.744 \mathrm{~d}$ & $1.412 b c$ \\
\hline $\mathrm{Mi}$ & \multicolumn{2}{|c|}{0 ------- Tb -------- 20} & & & \\
\hline 0 & $2.322 \mathrm{a}^{\mathrm{z}}$ & $2.767 \mathrm{a}$ & \multicolumn{2}{|c|}{$2.600 \mathrm{a}^{\mathrm{x}}$} & $2.758 \mathrm{a}$ \\
\hline 4 & $2.448 \mathrm{a}$ & $1.759 \mathrm{~b}$ & \multicolumn{2}{|c|}{$1.159 \mathrm{~b}$} & $1.641 \mathrm{~b}$ \\
\hline 8 & $2.367 \mathrm{a}$ & $1.345 \mathrm{~b}$ & & & $1.432 \mathrm{~b}$ \\
\hline \multicolumn{6}{|l|}{$\mathrm{Tb}$} \\
\hline \multicolumn{5}{|l|}{0} & $2.134 \mathrm{a}$ \\
\hline \multicolumn{5}{|l|}{20} & $1.737 \mathrm{~b}$ \\
\hline
\end{tabular}

"Soils were infested at planting with 4 or 8 eggs and second stage juveniles (J2) of M. incognita/g of soil.

${ }^{\mathrm{v}}$ Soils were infested at planting with 20 chlamydospores chains of $T$. basicola/g of soil.

${ }^{\text {w }}$ Root weight was measured 45 to 50 days after planting.

${ }^{\mathrm{x}}$ Means for a year and main effect followed by a common letter are not significantly different, Fisher's protected least significant difference $(P \leq 0.05)$.

${ }^{y}$ Interaction means for any sand and $\mathrm{Tb}$ combination followed by the same letter are not significantly different, Fisher's protected least significant difference $(P \leq 0.05)$

${ }^{\mathrm{z}}$ Interaction means for any $\mathrm{Mi}$ and $\mathrm{Tb}$ combination followed by the same letter are not significantly different, Fisher's protected least significant difference $(P \leq 0.05)$

Table 3. Main and interaction effects of soil texture (sand), Meloidogyne incognitav (Mi), and Thielaviopsis basicola ${ }^{\mathrm{w}}$ (Tb) on cotton development and yield

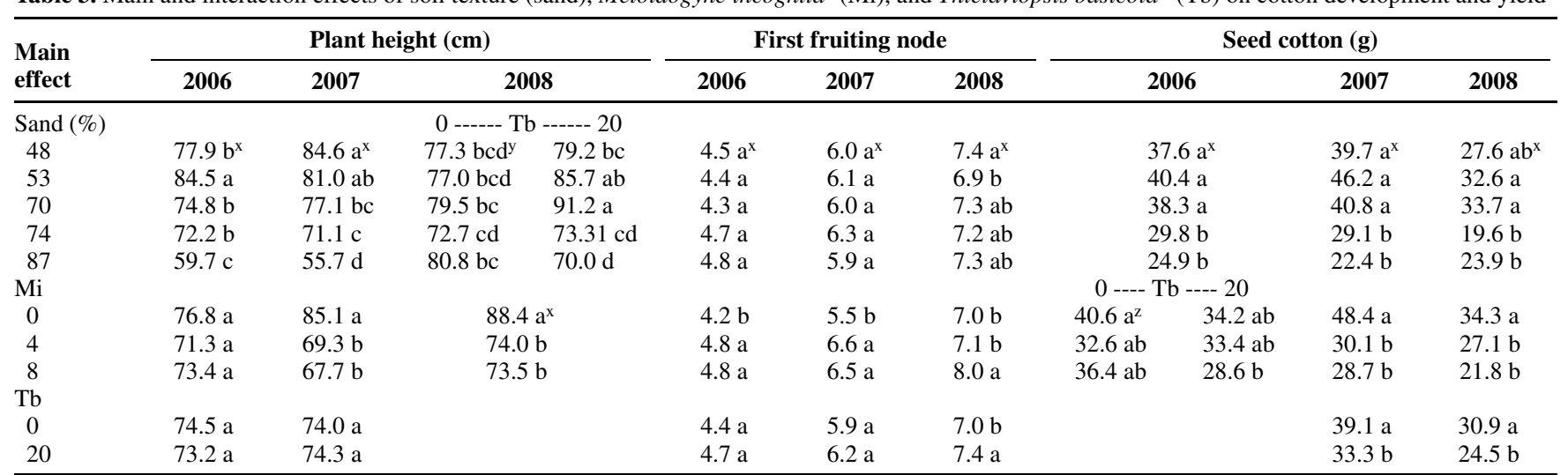

${ }^{\mathrm{v}}$ Soils were infested at planting with 4 or 8 eggs and second stage juveniles (J2) of M. incognita/g of soil.

${ }^{\text {w }}$ Soils were infested at planting with 20 chlamydospore chains of T. basicola/g of soil.

${ }^{x}$ Means for a year and main effect followed by a common letter are not significantly different, Fisher's protected least significant difference $(P \leq 0.05)$.

${ }^{y}$ Interaction means for any sand and $\mathrm{Tb}$ combination followed by the same letter are not significantly different, Fisher's protected least significant difference $(P \leq 0.05)$.

${ }^{\mathrm{z}}$ Interaction means for any Mi and $\mathrm{Tb}$ combination followed by the same letter are not significantly different, Fisher's protected least significant difference $(P \leq 0.05)$. 
also lower in soils infested with either $M$. incognita or T. basicola in 2 of the 3 years of this study (Table 3). In 2006, the greater inoculum rate of the nematode with $T$. basicola reduced yields compared with the noninfested treatment.

Pathogen responses. Root galling was affected by $T$. basicola early in the season in both 2007 and 2008 and midseason in 2007 (Supplementary Table S3). Soil texture influenced galling at midseason in 2008 and $M$. incognita infestation level influenced midseason galling in 2006. Significant interactions between soil texture and M. incognita were observed midseason in 2008 and a soil texture-T. basicola interaction occurred midseason in 2007. In 2008, galling tended to be numerically greater at higher sand contents (Table 4). Where T. basicola was present, root galling by $M$. incognita was suppressed both early in the season in 2007 and 2008 and at midseason in 2007 (Table 4).

$M$. incognita population density at harvest was affected by soil texture in both 2007 and 2008, while T. basicola had an effect on nematode reproduction in 2006 and 2007. In both 2006 and 2008, a soil-T. basicola interaction was present for nematode population density at harvest. $T$. basicola reduced $M$. incognita populations over all soil textures in 2007 compared with plots that were not infested with $T$. basicola (Table 5). In 2006, where T. basicola and
$M$. incognita were both present, nematode reproduction was suppressed in plots with sand content lower than $87 \%$, with significant nematode population reductions in soils with sand contents of 48,53, and $74 \%$ compared with soils that were not infested with $T$. basicola. In 2008, significant population density reductions were observed for $M$. incognita in the presence of $T$. basicola for $48 \%$ sand compared with other soil textures with or without T. basicola, except for $74 \%$ sand (Table 5). In 2007, nematode reproduction was greater in the soils with 53,74 , and $87 \%$ sand than with 48 or $70 \%$ sand and the response was similar in 2008 in the presence of $T$. basicola.

Soil texture influenced root colonization by $T$. basicola in both 2006 and 2008 (Supplementary Table S4). M. incognita did not affect root colonization, and there was no interaction between soil texture and the nematode. Root colonization by $T$. basicola was very high in 2007 and was not influenced by soil texture (Table 6) In 2006, root colonization was lower in the $87 \%$ sand compared with the other textures. In 2008, root colonization by $T$. basicola varied greatly but was lower in soils with 53,70 and $87 \%$ sand than in 48 and $74 \%$ sand. Soil populations of $T$. basicola were affected by soil texture at midseason in all 3 years and at harvest in 2007 and 2008. Soil populations of T. basicola at midseason and at

Table 4. Main and interaction effects of soil texture (sand), Meloidogyne incognita populations ${ }^{\mathrm{u}}(\mathrm{Mi})$, and Thielaviopsis basicola ${ }^{\mathrm{v}}$ (Tb) on cotton root gall ratings ${ }^{\mathrm{w}}$

\begin{tabular}{|c|c|c|c|c|c|c|c|c|}
\hline \multirow[b]{2}{*}{ Main effect } & \multicolumn{3}{|c|}{ Galling, early season } & \multicolumn{5}{|c|}{ Galling, midseason } \\
\hline & 2006 & 2007 & 2008 & 2006 & & & & \\
\hline Sand (\%) & \multirow[b]{2}{*}{$18.3 \mathrm{a}^{\mathrm{x}}$} & \multirow[b]{2}{*}{$15.3 \mathrm{a}^{\mathrm{x}}$} & \multirow[b]{2}{*}{$30.8 \mathrm{a}^{\mathrm{x}}$} & \multirow[b]{2}{*}{$10.6 \mathrm{a}^{\mathrm{x}}$} & \multicolumn{2}{|c|}{ 0-------Tb-------20 } & \multicolumn{2}{|c|}{ 4-------Mi-------8 } \\
\hline 48 & & & & & $48.4 b c^{y}$ & $1.2 \mathrm{~d}$ & $12.6 \mathrm{bcd}^{\mathrm{z}}$ & $1.2 \mathrm{~d}$ \\
\hline 53 & $9.9 \mathrm{a}$ & $12.6 \mathrm{a}$ & $40.9 \mathrm{a}$ & $2.9 \mathrm{a}$ & $70.7 \mathrm{ab}$ & $0.4 \mathrm{~d}$ & $43.7 \mathrm{ab}$ & $50.2 \mathrm{a}$ \\
\hline 70 & $10.6 \mathrm{a}$ & $12.4 \mathrm{a}$ & $35.7 \mathrm{a}$ & $2.3 \mathrm{a}$ & $57.9 \mathrm{abc}$ & $0.6 \mathrm{~d}$ & $56.9 \mathrm{a}$ & $7.5 \mathrm{~cd}$ \\
\hline 74 & $11.0 \mathrm{a}$ & $26.5 \mathrm{a}$ & $51.3 \mathrm{a}$ & $4.0 \mathrm{a}$ & $75.0 \mathrm{a}$ & $0.7 \mathrm{~d}$ & $36.1 \mathrm{abc}$ & $57.1 \mathrm{a}$ \\
\hline 87 & $10.6 \mathrm{a}$ & $19.6 \mathrm{a}$ & $64.0 \mathrm{a}$ & $5.8 \mathrm{a}$ & $39.9 \mathrm{c}$ & $3.4 \mathrm{~d}$ & $65.6 \mathrm{a}$ & $65.8 \mathrm{a}$ \\
\hline \multicolumn{9}{|l|}{$\mathrm{Mi}$} \\
\hline 4 & $12.3 \mathrm{a}$ & $11.9 \mathrm{a}$ & $49.8 \mathrm{a}$ & $23.0 \mathrm{a}$ & & & & \\
\hline 8 & $14.5 \mathrm{a}$ & $25.0 \mathrm{a}$ & $39.3 \mathrm{a}$ & $7.3 \mathrm{~b}$ & & & & \\
\hline \multicolumn{9}{|l|}{$\mathrm{Tb}$} \\
\hline 0 & $15.0 \mathrm{a}$ & $24.4 \mathrm{a}$ & $50.8 \mathrm{a}$ & $4.2 \mathrm{a}$ & & & \multicolumn{2}{|c|}{$37.7 \mathrm{a}^{\mathrm{x}}$} \\
\hline 20 & $11.8 \mathrm{a}$ & $2.7 \mathrm{~b}$ & $38.3 \mathrm{~b}$ & $6.1 \mathrm{a}$ & & & \multicolumn{2}{|c|}{$41.5 \mathrm{a}$} \\
\hline
\end{tabular}

u Soils were infested at planting with 4 or 8 eggs and second stage juveniles (J2) of M. incognita/g of soil.

${ }^{\mathrm{V}}$ Soils were infested at planting with 20 chlamydospore chains of T. basicola/g of soil.

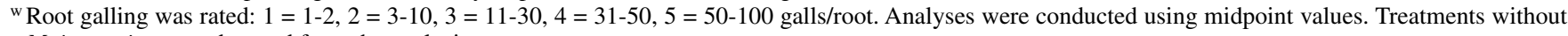
$M$. incognita were dropped from the analysis.

${ }^{x}$ Means for a year and main effect followed by a common letter are not significantly different, Fisher's protected least significant difference $(P \leq 0.05)$.

${ }^{y}$ Interaction means for any sand and $\mathrm{Tb}$ combination followed by the same letter are not significantly different, Fisher's protected least significant difference $(P \leq 0.05)$.

${ }^{\mathrm{z}}$ Interaction means for any sand and Mi combination followed by the same letter are not significantly different, Fisher's protected least significant difference $(P \leq 0.05)$.

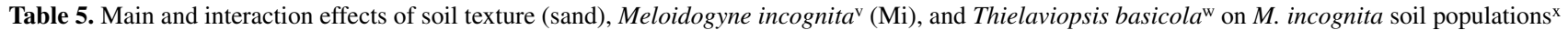

\begin{tabular}{|c|c|c|c|c|c|c|c|c|}
\hline \multirow[b]{2}{*}{ Main effect } & \multicolumn{5}{|c|}{ Harvest $M$. incognita population } & \multicolumn{3}{|c|}{ Preplant $M$. incognita population } \\
\hline & \multicolumn{2}{|c|}{2006} & 2007 & \multicolumn{2}{|c|}{2008} & 2007 & 2008 & 2009 \\
\hline Sand (\%) & \multicolumn{2}{|c|}{ 0-----Tb-----20 } & & \multicolumn{2}{|c|}{ 0------Tb------20 } & & & \\
\hline 48 & $2.9 \mathrm{ab}^{\mathrm{y}}$ & $1.7 \mathrm{~cd}$ & $1.3 \mathrm{~b}^{\mathrm{z}}$ & $2.5 \mathrm{~b}^{\mathrm{y}}$ & $1.8 \mathrm{c}$ & $2.5 \mathrm{a}^{\mathrm{z}}$ & $2.2 \mathrm{a}^{\mathrm{z}}$ & $1.8 \mathrm{c}^{\mathrm{z}}$ \\
\hline 53 & $2.8 \mathrm{abc}$ & $1.6 \mathrm{~d}$ & $2.6 \mathrm{a}$ & $2.7 \mathrm{~b}$ & $2.8 \mathrm{ab}$ & $1.9 \mathrm{a}$ & $1.8 \mathrm{a}$ & $2.4 \mathrm{ab}$ \\
\hline 70 & $2.8 \mathrm{abc}$ & $1.9 \mathrm{bcd}$ & $1.3 \mathrm{~b}$ & $2.7 \mathrm{~b}$ & $3.0 \mathrm{ab}$ & $1.7 \mathrm{a}$ & $2.0 \mathrm{a}$ & $2.3 \mathrm{bc}$ \\
\hline 74 & $3.1 \mathrm{a}$ & $1.4 \mathrm{~d}$ & $2.4 \mathrm{a}$ & $2.9 \mathrm{ab}$ & $2.4 \mathrm{bc}$ & $2.3 \mathrm{a}$ & $1.9 \mathrm{a}$ & $2.1 \mathrm{bc}$ \\
\hline 87 & $2.4 \mathrm{abc}$ & $2.8 \mathrm{ab}$ & $2.6 \mathrm{a}$ & $3.0 \mathrm{ab}$ & $3.5 \mathrm{a}$ & $2.4 \mathrm{a}$ & $1.9 \mathrm{a}$ & $2.9 \mathrm{a}$ \\
\hline \multicolumn{9}{|l|}{$\mathrm{Mi}$} \\
\hline 4 & \multirow{2}{*}{\multicolumn{2}{|c|}{$\begin{array}{l}2.4 \mathrm{a}^{\mathrm{z}} \\
2.3 \mathrm{a}\end{array}$}} & $2.1 \mathrm{a}$ & \multicolumn{2}{|c|}{$2.8 \mathrm{a}^{\mathrm{z}}$} & $2.2 \mathrm{a}$ & $2.1 \mathrm{a}$ & $2.3 \mathrm{a}$ \\
\hline 8 & & & $1.9 \mathrm{a}$ & & & $2.2 \mathrm{a}$ & $1.9 \mathrm{a}$ & $2.3 \mathrm{a}$ \\
\hline \multicolumn{9}{|l|}{$\mathrm{Tb}$} \\
\hline 0 & & & $3.2 \mathrm{a}$ & & & $2.2 \mathrm{a}$ & $2.1 \mathrm{a}$ & $2.3 \mathrm{a}$ \\
\hline 20 & & & $0.8 \mathrm{~b}$ & & & $2.1 \mathrm{a}$ & $1.8 \mathrm{a}$ & $2.3 \mathrm{a}$ \\
\hline
\end{tabular}

${ }^{\mathrm{v}}$ Soils were infested at planting with 4 or 8 eggs and second stage juveniles (J2) of $M$. incognita/g of soil.

${ }^{\mathrm{w}}$ Soils were infested at planting with 20 chlamydospore chains of $T$. basicola/g of soil.

${ }^{x}$ Treatments without $M$. incognita were dropped for this analysis. Data transformed, $\log _{10}(x+1)$.

${ }^{y}$ Interaction means for any sand and $\mathrm{Tb}$ combination followed by the same letter are not significantly different, Fisher's protected least significant difference $(P \leq 0.05)$.

${ }^{\mathrm{z}}$ Means for a year and main effect followed by a common letter are not significantly different, Fisher's protected least significant difference $(P \leq 0.05)$. 
harvest were lower in $87 \%$ sand than the other soil textures, except at harvest in 2006 (Table 7).

The preplant populations of $M$. incognita were affected by soil texture in 2009. Population densities were greater for $87 \%$ sand than all but the $53 \%$ sand treatment (Table 5). The populations of T. basicola the following spring were affected by soil texture in 2007 and 2009. In 2007, M. incognita also affected preplant populations and there was a texture-nematode interaction. In 2007, T. basicola survival was greater when the nematode was present in most soil textures, except in soil with 70 and $74 \%$ sand content. Survival of T. basicola was greater in soil with sand contents below $87 \%$ in 2009 (Table 7).

\section{Discussion}

T. basicola reduced plant height, the number of main stem nodes, and root weight in 2 of the 3 years of the study (2007 and 2008) both early in the season and at midseason. In earlier studies in microplots, Walker et al. $(37,39)$ documented few effects of $T$. basicola on plant growth in the absence of the nematode, with the height-to-node ratio being less than that in the noninfested control in 1 year at an infestation rate of 100 chlamydospores/g of soil at 21 or 28 DAP (39). In a later study, Walker et al. (37) again observed that $T$. basicola had little impact on plant growth in the absence of the nematode except to reduce plant weight in one sea-

Table 6. Main effects of soil texture (sand) and Meloidogyne incognita (Mi) on percent root colonization by Thielaviopsis basicola ${ }^{\mathrm{y}}$

\begin{tabular}{lllr}
\hline Main effect & $\mathbf{2 0 0 6}$ & $\mathbf{2 0 0 7}$ & $\mathbf{2 0 0 8}$ \\
\hline Sand (\%) & & & \\
48 & $57.0 \mathrm{a}^{\mathrm{z}}$ & $95.0 \mathrm{a}$ & $86.2 \mathrm{a}$ \\
53 & $61.2 \mathrm{a}$ & $80.0 \mathrm{a}$ & $19.2 \mathrm{~b}$ \\
70 & $57.5 \mathrm{a}$ & $92.5 \mathrm{a}$ & $8.4 \mathrm{~b}$ \\
74 & $60.8 \mathrm{a}$ & $86.1 \mathrm{a}$ & $88.3 \mathrm{a}$ \\
87 & $23.6 \mathrm{~b}$ & $80.0 \mathrm{a}$ & $6.2 \mathrm{~b}$ \\
$\mathrm{Mi}$ & & & \\
0 & $63.5 \mathrm{a}$ & $88.9 \mathrm{a}$ & $45.5 \mathrm{a}$ \\
4 & $45.0 \mathrm{a}$ & $83.3 \mathrm{a}$ & $43.6 \mathrm{a}$ \\
8 & $48.2 \mathrm{a}$ & $76.8 \mathrm{a}$ & $37.7 \mathrm{a}$ \\
\hline
\end{tabular}

${ }^{\mathrm{x}}$ Soils were infested at planting with 4 or 8 eggs and second stage juveniles (J2) of M. incognita/g of soil.

${ }^{y}$ Soils were infested at planting with 20 chlamydospore chains of $T$. basicola/g of soil. Root discoloration and colonization: $0=$ none, $1=1-$ $10 \%, 2=11-20 \%, 3=21-30 \%, 4=31-40,5=41-50,6=51-60 \%, 7=$ $61-70 \%, 8=71-80 \%, 9=81-90 \%$, and $10=91-100 \%$. Analyses were conducted using midpoint values. Treatments without $T$. basicola were dropped from the analyses.

${ }^{\mathrm{z}}$ Means in a column for a year and main effect followed by a common letter are not significantly different, Fisher's protected least significant difference $(P \leq 0.05)$. son at 56 DAP (39). The reduction in plant growth early in the season in soils infested with $T$. basicola in the current study corresponded to lower seed-cotton yield in both 2007 and 2008. Yield reductions from $T$. basicola have not been observed in the absence of the nematode in previous microplot studies $(37,39)$. Severity of black root rot on cotton increases at soil temperatures below $24^{\circ} \mathrm{C}$ and in poorly drained soils $(20,23,30,38)$. The variable impact of $T$. basicola on disease development and severity and cotton growth and yield in the current study may be related to differences in soil environment at or shortly after planting among the 3 years of this study. T. basicola had the greatest root colonization and the greatest impact on cotton growth and yield in 2007. The 2007 season was characterized by lower soil temperatures in May and June than in the other years of the study. Soil temperatures early in the season were similar to or lower than the 2007 temperatures in the previous microplot studies; however, root discoloration and colonization or incidence was much lower in the former studies $(37,39)$. These results suggest that the greater level of early-season colonization accounted for the yield losses observed with T. basicola in this study. The year 2006 had the lowest levels of root colonization (52\% colonization) and also was the year with a $T$. basicola-M. incognita interaction that resulted in greater losses than T. basicola alone. This is similar to previous work. The other soil factor that may have impacted the level of black root rot observed in this study was the soil texture used in these studies. The base soil for this study was a silt-loam soil compared with a fine-sandy-loam soil that was used in the previous microplot studies (71\% sand, $17 \%$ silt, and $12 \%$ clay) (37,39); a soil that would favor $T$. basicola.

The effect of soil texture on T. basicola was evident, with soils having $87 \%$ sand content exhibiting lower root colonization and reproduction of the T. basicola in both 2006 and 2008 compared with other soil textures. The effects of soil texture on $T$. basicola were also evident for root weight. The interaction between soil texture and T. basicola for root weight early in the 2008 season or midseason in 2007 showed that the fungus had no effect on root weight for soil textures with a high sand content. Buchanan (4), using a benomyl-resistant isolate of $T$. basicola, reported that the isolation frequency of $T$. basicola from cotton decreased in field soil using the same pathogen population as sand content increased to $76 \%$ compared with soil textures with soils with lower sand contents from the same field. Monfort (22) observed that populations of $T$. basicola were lower in areas of a field with the greatest sand content (50.1 to $81.7 \%$ sand) compared with other classifications of 22 to $50 \%$ sand.

M. incognita also affected plant growth early in the season but the nematode effects were more consistent on plant growth later in the season, when soil temperatures were warmer. M. incognita reduced early-season plant height and number of nodes only in

Table 7. Main effects and interaction of soil texture (soil) and Meloidogyne incognita ${ }^{\mathrm{w}}(\mathrm{Mi})$ on Thielaviopsis basicola populations ${ }^{\mathrm{x}}$

\begin{tabular}{|c|c|c|c|c|c|c|c|c|c|c|c|}
\hline \multirow{2}{*}{$\begin{array}{l}\text { Main } \\
\text { effect }\end{array}$} & \multicolumn{3}{|c|}{ Midseason } & \multicolumn{3}{|c|}{ Harvest } & \multicolumn{5}{|c|}{ Preplant } \\
\hline & 2006 & 2007 & 2008 & 2006 & 2007 & 2008 & & 2007 & & 2008 & 2009 \\
\hline Sand $(\%)$ & & & & & & & 0----י & $\mathrm{Mi}$ & ---8 & & \\
\hline 48 & $2.8 \mathrm{a}^{\mathrm{y}}$ & $2.5 b c^{y}$ & $2.6 \mathrm{a}^{\mathrm{y}}$ & $4.0 \mathrm{a}^{\mathrm{y}}$ & $2.8 a^{y}$ & $2.6 \mathrm{a}^{\mathrm{y}}$ & $1.6 \mathrm{bc}^{\mathrm{z}}$ & $3.2 \mathrm{a}$ & $3.2 \mathrm{a}$ & $2.7 \mathrm{a}^{\mathrm{y}}$ & $5.3 \mathrm{a}^{\mathrm{y}}$ \\
\hline 53 & $2.5 \mathrm{a}$ & $3.0 \mathrm{a}$ & $1.6 \mathrm{~b}$ & $5.1 \mathrm{a}$ & $2.5 \mathrm{bc}$ & $2.5 \mathrm{a}$ & $0.0 \mathrm{~d}$ & $2.4 \mathrm{a}$ & $3.2 \mathrm{a}$ & $2.6 \mathrm{a}$ & $5.2 \mathrm{a}$ \\
\hline 70 & $2.5 \mathrm{a}$ & $2.9 \mathrm{ab}$ & $1.7 \mathrm{bc}$ & $4.1 \mathrm{a}$ & $2.8 \mathrm{a}$ & $2.2 \mathrm{~b}$ & $3.2 \mathrm{a}$ & $3.1 \mathrm{a}$ & $3.05 \mathrm{a}$ & $2.7 \mathrm{a}$ & $5.0 \mathrm{a}$ \\
\hline 74 & $2.2 \mathrm{a}$ & $2.9 \mathrm{ab}$ & $2.7 \mathrm{a}$ & $4.8 \mathrm{a}$ & $2.7 \mathrm{ab}$ & $2.6 \mathrm{a}$ & $3.1 \mathrm{a}$ & $3.1 \mathrm{a}$ & $3.1 \mathrm{a}$ & $2.8 \mathrm{a}$ & $4.8 \mathrm{a}$ \\
\hline 87 & $1.4 \mathrm{~b}$ & $2.3 \mathrm{c}$ & $1.1 \mathrm{c}$ & $4.1 \mathrm{a}$ & $2.4 \mathrm{c}$ & $1.6 \mathrm{c}$ & $1.1 \mathrm{c}$ & $2.3 a b$ & $2.3 \mathrm{a}$ & $2.5 \mathrm{a}$ & $3.6 \mathrm{~b}$ \\
\hline \multicolumn{12}{|l|}{$\mathrm{Mi}$} \\
\hline 0 & $2.4 \mathrm{a}$ & $2.7 \mathrm{a}$ & $1.7 \mathrm{a}$ & $4.3 \mathrm{a}$ & $2.7 \mathrm{a}$ & $2.1 \mathrm{a}$ & & & & $2.7 \mathrm{a}$ & $4.6 \mathrm{a}$ \\
\hline 4 & $2.3 \mathrm{a}$ & $2.7 \mathrm{a}$ & $2.1 \mathrm{a}$ & $4.7 \mathrm{a}$ & $2.5 \mathrm{a}$ & $2.3 \mathrm{a}$ & & & & $2.5 \mathrm{a}$ & $5.0 \mathrm{a}$ \\
\hline 8 & $2.1 \mathrm{a}$ & $2.7 \mathrm{a}$ & $2.1 \mathrm{a}$ & $4.3 \mathrm{a}$ & $2.7 \mathrm{a}$ & $2.4 \mathrm{a}$ & & & & $2.7 \mathrm{a}$ & $4.8 \mathrm{a}$ \\
\hline
\end{tabular}

${ }^{\text {w }}$ Soils were infested at planting with 4 or 8 eggs and second stage juveniles (J2) of $M$. incognita/g of soil.

${ }^{x}$ Soils were infested at planting with 20 chlamydospore chains of $T$. basicola/g of soil. Data transformed, $\log _{10}(x+1)$. Treatments without $T$. basicola were dropped from the analyses.

${ }^{y}$ Means for a year and main effect followed by a common letter are not significantly different, Fisher's protected least significant difference $(P \leq 0.05)$.

${ }^{\mathrm{z}}$ Interaction means for any sand and Mi combination followed by the same letter are not significantly different, Fisher's protected least significant difference $(P \leq 0.05)$. 
2008, which was the warmest year early in the season. By midseason, when the soils were warmer, the nematode lowered all growth measurements in both 2007 and 2008. At harvest, the presence of $M$. incognita delayed initiation of the first sympodial fruiting branch in all 3 years and suppressed plant height, boll number, and seed cotton in 2007 and 2008. M. incognita is a warm-season, chronic pathogen that would likely become increasingly severe later in the growing season, when soils temperatures are warmer (38).

Soil texture had little effect on severity of the $M$. incognita over the range of sand content in this study. Soil textures with greater sand contents enhanced root galling in 2008. Koenning et al. (17) observed that the reproduction of $M$. incognita was greater in soils with $91 \%$ sand than in soils with sand contents of 48 or $53 \%$, and that the population density of the nematode was negatively related to the percent of clay and silt. The clay content in soils used by Koenning et al. (17) was greater (29 to $30 \%$ ) than the clay content in the soil used in this study (2\%) and may explain why few differences in populations of the nematode were found in this study. In surveys in the lower Rio Grande Valley in Texas, Robinson et al. (29) reported that $M$. incognita was associated with sandy-loam and silt-loam soils and, in a similar survey from across Texas, $M$. incognita rarely occurred in soil with greater than $40 \%$ clay (33). Monfort et al. (24) documented that $M$. incognita population densities at planting and the soil sand content explained from 65 to $86 \%$ of the variation seen in cotton yield, depending on the year. O'Bannon and Reynolds (27) also reported greater losses from $M$. incognita in cotton in loamy-sand and sandy-loam soils, with no losses in a silt loam or loam when comparing fumigated and nonfumigated soils.

Soil texture had some impact on plant growth in this study, with root weight being reduced at soil textures of 74 and $87 \%$ sand and height being less at $87 \%$ sand. Seed-cotton yields also were often the lowest for these soil textures. Water was managed for each soil texture in this study. As plant development progressed through the season, the amount of water added if rainfall did not occur may not have been sufficient to move into the lower soil profile, resulting in plant water stress and accounting for these soil texture effects. In the field, Monfort et al. (24) suggested that differences in plant growth and yield may have reflected changes in soil factors such as water and nutrient availability for growth, where these inputs are applied uniformly across the field. Water management by soil texture may partially explain why damage was less across the soil textures in this microplot study.

Interactions between T. basicola and M. incognita were not consistently detected in the 3 years of this study but the effects were consistent whenever they did occur. An interaction between the fungus and the nematode for seedling height and root weight and for yield occurred in 2006, the year in which severity of nematode galling was the lowest and $T$. basicola caused little damage in the absence of the nematode. Disease severity was greater when the interaction occurred than where either pathogen was present alone, as has been shown in previous studies (37-39). In the previous microplot studies, $T$. basicola and $M$. incognita did not cause appreciable damage by themselves and the interaction between $M$. incognita and T. basicola was observed $(37,39)$. Nematode infection did not increase root discoloration or colonization of $T$. basicola in these studies. Root galling was, however, reduced by the presence of T. basicola in 2007 at both early and midseason. The 2007 season was also the year with the greatest colonization of roots by the fungus. Soil conditions after planting that were favorable for T. basicola may have allowed the fungus to colonize and damage the root tissue sufficiently to lower the suitability of the host for the nematode. T. basicola affected harvest populations of $M$. incognita all 3 years, with populations being influenced by a significant soil texture-T. basicola interaction in 2 of the 3 years. Nematode populations were reduced by T. basicola in 2006 for all textures below $87 \%$ sand and the $48 \%$ sand soil in 2008 . However, this did not affect spring populations of the nematode.

No consistent soil texture- $T$. basicola-M. incognita interaction was observed for plant development or yield. The most important texture effect appears to be limiting the activity of $T$. basicola at increased sand contents. Previous work examining the role of soil texture on potato early dying caused by Pratylenchus penetrans and Verticillium dahliae did not find that the disease complex was affected in Wooster silt loam, Spinks fine sand, and Rifle peat in microplots, even though P. penetrans caused more yield loss in the sandy soil (7). M. incognita and T. basicola are widely distributed in Arkansas cotton fields at levels that are capable of affecting plant growth and yield $(24,31)$. However, the presence of these pathogens in the soil may not be the limiting factor for yield due to environment. These results support previous studies showing that $T$. basicola and $M$. incognita distribution in cotton fields is influenced by sand content $(22,24)$. Population densities of $T$. basicola are more likely to be present in areas with lower sand contents, while soils with greater sand contents would be more conducive to larger populations of $M$. incognita. Areas with concomitant infestation by both pathogens may increase disease severity and damage to cotton, because these pathogens are known to interact in a synergistic manner (37-39). Management of $M$. incognita using chemical nematicides may be an important strategy to reduce the damage caused whenever these two pathogens are present in the same soil (24). The use of triazole fungicides to suppress T. basicola may also minimize losses (34). Because soil texture is a stable soil property, and the association of the nematode population densities to sand particle distribution in soils remains similar over the years, as demonstrated by Monfort (24), soil textural maps may be useful for making management decisions. The use of field textural maps in the management of $M$. incognita also may allow growers to include site-specific nematicide application for anticipating areas where losses from this nematode-fungus interaction would increase losses under a favorable environment.

\section{Literature Cited}

1. Allen, S. J. 2001. Black root rot. Pages 16-17 in: Compendium of Cotton Diseases, Second Edition. T. L. Kirkpatrick and C. S. Rothrock, eds. American Phytopathological Society, St. Paul, MN.

2. Arshad, M. A., Lowery, B., and Grossman, B. 1996. Physical tests for monitoring soil quality. Pages 123-141 in: Methods for Assessing Soil Quality. J. W. Doran and A. J. Jones, eds. Soil Sci. Soc. Am. Spec. Publ. 49. Soil Science Society of America, Madison, WI.

3. Bourland, F. M., and Watson, C. E. 1990. COTMAP, a technique evaluating structure and yield of cotton. Crop Sci. 30:224-226.

4. Buchanan, M. L. 2005. Developing a decision aid for the use of in-furrow fungicides. M.Sc. dissertation, University of Arkansas, Fayetteville.

5. Byrd, D. W., Jr., Barker, K. R., Ferris, H., Nusbaum, C. J., Griffin, W. E., Small, R. H., and Stone, C. A. 1976. Two semi-automatic elutriators for extracting nematodes and certain fungi from soil. J. Nematol. 8:206-212.

6. Candole, B. L., and Rothrock, C. S. 1997. Characterization of the suppressiveness of hairy vetch-amended soils to Thielaviopsis basicola. Phytopathology 87:197-202.

7. Francl, L. J., Rowe, R. C., Riedel, R. M., and Madden, L. V. 1988. Effects of three soil types on potato early dying disease and associated yield reduction. Phytopathology 78:159-166.

8. Goodell, P. B., and Ferris, H. 1989. Influence of environmental factors on the hatch and survival of Meloidogne incognita. J. Nematol. 21:328-334.

9. Griffin, D. M. 1972. Ecology of Soil Fungi. Syracuse University Press, Syracuse, NY.

10. Heald, C. M., and Orr, C. C. 1994. Nematode parasites of cotton. Pages 148-153 in: Plant and Insect Nematodes. W. R. Nickle, ed. M. Dekker, Inc., New York.

11. Hood, M. E., and Shew, H. D. 1997. Reassessment of the role of saprophytic activity in the ecology of Thielaviopsis basicola. Phytopathology 87:1214-1219.

12. Hussey, R. S., and Barker, K. R. 1973. A comparison of methods of collecting inocula of Meloidogyne spp., including a new technique. Plant Dis. Rep. 57:1025-1028.

13. Jenkins, W. R. 1964. A rapid centrifugal flotation technique for separating nematodes from soil. Plant Dis. Rep. 48:692.

14. Johnson, J., and Hartman, R. E. 1916. Influence of soil environment on the root-rot of tobacco. J. Agric. Res. 17:41-86.

15. King, C. J., and Presley, J. T. 1942. A root rot of cotton caused by Thielaviopsis basicola. Phytopathology 32:752-761.

16. Kirkpatrick, T. L., and Rothrock, C. S. 2001. Compendium of Cotton Diseases, 2nd ed. American Phytopathological Society, St. Paul, MN.

17. Koenning, S. R., Walters, S. A., and Barker, K. R. 1996. Impact of soil texture on the reproductive and damage potentials of Rotylenchulus reni- 
formis and Meloidogyne incognita on cotton. J. Nematol. 28:527-536.

18. Koenning, S. R., Wrather, J. A., Kirkpatrick, T. L., Walker, N. R., Starr, J. L., and Mueller, J. D. 2004. Plant-parasitic nematodes attacking cotton in the United States: Old and emerging production challenges. Plant Dis. 88:100-113.

19. Mathre, D. E., Ravenscroft, A. V., and Garber, R. H. 1966. The role of Thielaviopsis basicola as a primary cause of yield reduction in cotton in California. Phytopathology 56:1213-1216.

20. Mauk, P. A., and Hine, R. B. 1988. Infection, colonization of Gossypium hirsutum and $G$. barbadense, and development of black root rot caused by Thielaviopsis basicola. Phytopathology 78:1662-1667.

21. McClure, M. A. 1977. Meloidogyne incognita: a metabolic sink. J. Nematol. 9:88-90.

22. Monfort, W.S. 2005. Potential for remote identification of within-field problem zones associate with Meloidogyne incognita and Thielaviopsis basicola for site-specific control in cotton. Ph.D. dissertation, University of Arkansas, Fayetteville.

23. Monfort, W.S., Kirkpatrick, T. L., and Rothrock, C. S. 2006. Effects of nocturnal soil temperature and Meloidogyne incognita densities on cotton seedling growth and the interaction with Thielaviopsis basicola. Plant Dis. 90:519-522.

24. Monfort, W.S., Kirkpatrick, T. L., Rothrock, C. S., and Mauromoustakos, A. 2007. Potential for site-specific management of Meloidogyne incognita in cotton using soil textural zones. J. Nematol. 39:1-8.

25. Nan, Z. B., Long, P. G., Skipp, R. A., and Hopcroft, D. H. 1992. Microscopy of invasion of red clover root by Trichocladium basicola, and effects of benomyl and prochloraz. Plant Pathol. 41:449-461.

26. National Oceanic and Atmospheric Administration (NOAA). 2010. Climatological data of Arkansas. www.ncdc.noaa.gov/mpp.html

27. O'Bannon, J. H., and Reynolds H. W. 1961. Root-knot nematode damage and cotton yields in relation to soil properties. Soil Sci. 92:384-386.

28. Prot, J. C., and Van Gundy, S. D. 1981. Effect of the soil texture and the clay component on migration of Meloidogyne incognita second stage juveniles. J. Nematol. 13:213-216.

29. Robinson, A. F., Heald, C. M., Flanagan, S. L., Thames, W. H., and Ama- dor, J. 1987. Geographic distributions of Rotylenchulus reniformis, Meloidogyne incognita, and Tylenchulus semipenetrans in the Lower Rio Grande Valley as related to soil texture and land use. Ann. Appl. Nematol. 1:20-25.

30. Rothrock, C. S. 1992. Influence of soil temperature, water, and texture on Thielaviopsis basicola and black root rot on cotton. Phytopathology 82:1202-1206.

31. Rothrock, C. S. 1997. Prevalence and distribution Thielaviopsis basicola. Pages 75-77 in: Proc. Beltwide Cotton Prod. Conf. National Cotton Council of America, Memphis, TN.

32. Specht, L. H., and Griffin, G. J. 1985. A selective medium for enumerating low populations of Thielaviopsis basicola. Can. J. Plant Pathol. 7:438-441.

33. Starr, J. L., Heald, C. M., Robinson, A. F., Smith, R. G., and Krausz, J. P. 1993. Meloidogyne incognita and Rotylenchulus reniformis and associated soil textures from some cotton production areas of Texas. Suppl. J. Nematol. 25:895-899.

34. Toksoz, H., Rothrock, C. S., and Kirkpatrick, T. L. 2009. Efficacy of seed treatment chemicals for black root rot, caused by Thielaviopsis basicola, on cotton. Plant Dis. 93:354-362.

35. Towson, A. J., and Apt, W. J. 1983. Effect of soil water potential on survival of Meloidogyne javanica in fallow soil. J. Nematol. 15:110-115.

36. Van Gundy, S. D. 1985. Ecology of Meloidogyne spp.-emphasis on environmental factors affecting survival and pathogenicity. Pages 177-182 in An Advanced Treatise of Meloidogyne, Vol I: Biology and Control. J. N. Sasser and C. C. Carter, eds. North Carolina State University Graphics, Raleigh.

37. Walker, N. R., Kirkpatrick, T. L., and Rothrock, C. S. 1998. Interaction between Meloidogyne incognita and Thielaviopsis basicola on cotton (Gossypium hirsutum). J. Nematol. 30:415-422.

38. Walker, N. R., Kirkpatrick, T. L., and Rothrock, C. S. 1999. Effects of temperature on and the histopathology of the interaction between Meloidogyne incognita and Thielaviopsis basicola on cotton. Phytopathology 89:613-617.

39. Walker, N. R., Kirkpatrick, T. L., and Rothrock, C. S. 2000. Influence of Meloidogyne incognita and Thielaviopsis basicola populations on early-season disease development and cotton growth. Plant Dis. 84:449-453. 